\title{
Operation Car Wash: Impacts on the Executives' Liability Insurance Market
}

\author{
Operação Lava Jato: Impactos no Mercado Segurador de Responsabilidade \\ Civil de Executivos
}

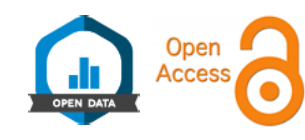

Rafael Tonet Rensi ${ }^{10}$ João Vinícius França Carvalho' ${ }^{10}$

\section{ABSTRACT}

Context: triggered in 2014, the Car Wash Operation (CWO) belongs to a process of changing the legal context, in the sense of greater responsibility and penalization of public and private companies' decision makers for acts practiced in the exercise of their functions, object of the Directors' and Officers' liability insurance coverage $(\mathrm{D} \& \mathrm{O})$. Objective: to evaluate the relationship between the growth in the revenues of $\mathrm{D} \& \mathrm{O}$ insurance premiums and the developments of the OCW in Brazil, under the hypothesis of a change in the perception of economic agents exposed to risks covered by $\mathrm{D} \& \mathrm{O}$ insurance, in a process known as probability updating. Methods: official monthly data for all active insurers, arranged longitudinally between 2003 and 2017, and using two-stage regression method for panel data. Results: the OCW had a positive effect not only to the probability of offering this type of insurance, but also to increase the volume of D\&O premiums; these results are consistent with the probability-updating hypothesis. Conclusion: the OCW resulted in an increase in revenues of D\&O premiums, but there was a negative relationship between OCW and the entire insurance market, suggesting significance of this operation in the sector retraction observed since its outbreak.

Keywords: insurance; third party liabilities; Operation Car Wash; probability updating. $\overline{\text { 1. Universidade de São Paulo, Faculdade de Economia, Administração, Contabilidade e Atuária, São }}$ Paulo, SP, Brazil.

Cite as: Rensi, R.T., \& Carvalho, J.V.F. (2021). Operationcarwash:Impacts on the executives'liabilityinsurance market. Revista de Administração Contemporânea, 25(2), e190386. https://doi.org/10.1590/1982-7849rac2021 190386.en

\section{RESUMO}

Contexto: deflagrada em 2014, a Operação Lava Jato (OLJ) pertence a um processo de mudança de contexto jurídico no sentido de maior responsabilizaçáo e penalizaçáo de administradores públicos e privados por atos praticados no exercício de suas funções, objeto da cobertura securitária do seguro de Responsabilidade Civil de Administradores e Diretores (D\&O). Objetivo: avaliar a relação entre o crescimento da arrecadação de prêmios de seguros D\&O e os desdobramentos da operaçáo OLJ no Brasil, sob a hipótese de mudança na percepçáo de agentes econômicos expostos aos riscos cobertos pelo seguro $\mathrm{D} \& \mathrm{O}$, em processo conhecido como atualização de probabilidade. Métodos: dados mensais oficiais de todas as seguradoras ativas, dispostas longitudinalmente entre 2003 e 2017, e utilizando o método de regressão para dados em painel em dois estágios. Resultados: a OLJ teve relação significante não apenas para a probabilidade de oferta deste tipo de seguro, mas também sobre o aumento do volume de prêmios arrecadados de $\mathrm{D} \& \mathrm{O}$, sendo estes resultados consistentes com a hipótese da atualização de probabilidade. Conclusáo: a OLJ resultou em elevação dos prêmios arrecadados no ramo $\mathrm{D} \& \mathrm{O}$, mas verificou-se relação negativa da OLJ com todo o mercado segurador, sugerindo que a operação atuou na retração setorial observada desde a sua deflagração.

Palavras-chave: seguros; responsabilidade civil; Operação Lava Jato; atualizaçáo de probabilidade. Cristiano Forti (Universidade Federal de Uberlândia, FAGEN, Brazil) (1) Peer Review Report: The Peer Review Report is available at this external URL.

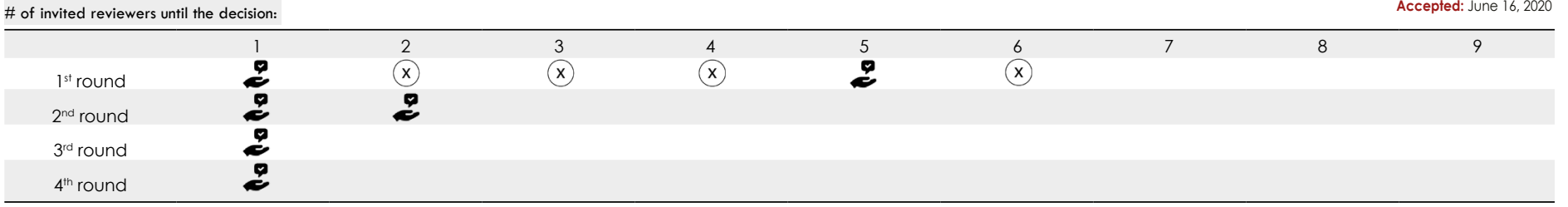




\section{INTRODUCTION}

The directors and officers liability insurance (D\&O) is designed to protect executives' assets in case they are held responsible for any harm to third parties, caused by the companies under their management. In the Brazilian market, this line of insurance business presented a unique development when compared to the entire insurance market in the recent period. According to data from the SES, Sistema de Estatísticas da Susep (Susep Statistics System), between 2014 and 2017 the volume of direct annual premiums' revenues (in nominal terms) increased by $9.92 \%$ on insurance companies of all lines, while the growth of the $\mathrm{D} \& \mathrm{O}$ line of business was $78 \%$.

There are indications that the atypical development of the $\mathrm{D} \& \mathrm{O}$ insurance market in Brazil in that period is related to the updating of economic agents on the perception of exposure to risks covered by that line of insurance since Operation Car Wash (CWO). Started in 2014, CWO belongs to a process of change in the Brazilian legal context toward greater liability and penalization of public and private companies' decision-makers for acts practiced in the exercise of their functions - precisely the object of D\&O's insurance coverage.

Even though the perception of greater risk of executives' liability for acts related to their boards is related to the breadth of the legal system, CWO, by itself, is significant enough to affect that perception, due to its scale and development. When started by the Brazilian Federal Police in March 2014, the operation was investigating the practice of financial crimes by organizations that operated in the clandestine foreign exchange market in Brazil, involving the cover up of assets, money laundering, and offshore account operations. The name 'Car Wash' refers to a chain of laundries and a gas station located in Brasília, used by one of the investigated organizations for moving illicit money.

There is important both actuarial and accounting literature in which it is usual to empirically address the factors associated with the demand for $\mathrm{D} \& \mathrm{O}$ insurance and its role in corporate governance (Gillan \& Panasian, 2015; Hwang \& Kim, 2018; Jia \& Tang, 2016; Lin, Officer, \& Zou, 2011). However, even in the United States, where the insurance industry underwrites more than US $\$ 5$ billion in annual D\&O insurance premiums only, there is a lack of research examining the insurance supply's side (Born \& Klimaszewski-Blettner, 2013; Fier \& Liebenberg, 2014). The natural consequence of that lack is that little is known about the industrial organization of this market and, therefore, about the characteristics of the insurers that decide to offer D\&O insurance. Particularly in Brazil, where studies on the decisions and performance of insurance companies are even more scarce (Macedo \& Corrar, 2010; Macedo, Silva, \& Santos, 2006), that lack is even greater, due to the specificities of this market.

If an event that indicates greater severity in the accountability of executives strongly affected the demand for $\mathrm{D} \& \mathrm{O}$ insurance, insurers would have greater problems with adverse selection. They would need to review the contractual clauses of the coverage offered and re-price the premiums. From the perspective of the State as a disciplinary agent, the relation between demand for $\mathrm{D} \& \mathrm{O}$ insurance and penalty for illicit acts should serve as a parameter to assess the effectiveness of the damage to the executives' assets, as a mechanism of coercion and constraining. Thus, an understanding of the uniqueness of $\mathrm{D} \& \mathrm{O}$ and the consequence of CWO in this market is necessary for the maturity of insurers and regulators over that line of business in the Brazilian context.

In this regard, the theoretical contribution is to assess the idiosyncratic profiles that characterize Brazilian insurance companies operating in the $\mathrm{D} \& \mathrm{O}$ insurance market, and whether CWO is an additional reason for the decision of offering such a product. More than that: once the insurers opted to offer the service, did CWO significantly increase the revenue of these companies? Is it the case that such an increase in revenue occurs only over insurances directly linked to the coverage $(\mathrm{D} \& \mathrm{O})$ or does that also happen over the rest of the market?

The main objective of this study is to evaluate the relation between the growth in revenues of $\mathrm{D} \& \mathrm{O}$ insurance premiums in Brazil and CWO, under the premise that the shock of demand for that type of protection occurred due to an updating on the perception of exposure to risks covered by that type of insurance, on the part of the exposed economic agents, after the developments of the operation, in a process known as probability updating (Fier, McCullough, Gabel, \& Mansfield, 2015). As a methodology, a two-stage regression method for panel data was used (Cragg, 1971) to quantify the effect of deflagrations from different CWO phases on the supply of insurance contracts, for the insurers. More specifically, the interest is to measure the effect of CWO (a) on the probability of insurers operating in the market offering D\&O insurances and (b) on the aggregate revenue, materialized in the volume of premium revenue.

The relevance of the operation's unfoldings from a political and economic angle in contemporary Brazilian history, the unprecedentedness of the practiced modus operandi, and the disclosure of private conversations of several parties involved in the process lead to a debate on the objectives and validity of the operation. It should be noted that the present study does not go into that debate, as the object of analysis on CWO is its attribution as an 
exogenous factor that might influence the decision to supply $\mathrm{D} \& \mathrm{O}$ insurance.

\section{D\&O INSURANCE IN BRAZIL}

The Brazilian insurance market is concentrated over a few lines of business. In $2017,53 \%$ of the 100.56 billion $\mathrm{BRL}$ in direct premiums issued by insurance companies were originated from the five largest lines: Auto - Hull, Life Group, Credit Life Insurance, Auto - Facultative Civil Liability, and DPVAT (a compulsory insurance for personal injury caused by motor vehicles). The remainder direct premiums issued in 2017 were distributed throughout the other 122 lines of insurance regulated by Susep. During this period, premiums underwritten of $\mathrm{D} \& \mathrm{O}$ insurance were
405 million BRL, representing $0.4 \%$ of the entire market's revenues. Figure 1 shows the market share of the premiums issued in 2017.

The revenue of premiums from the $\mathrm{D} \& \mathrm{O}$ insurance line in Brazil is not very significant in the face of the entire insurance market. That is natural, given the specificity of the line of business, but it is also a reflex of how incipient that line still is in Brazil. Another specificity of D\&O insurance in Brazil is the geographical concentration of premiums issued. In $2017,85.10 \%$ of the total direct premiums were issued in the southeast region, surpassing the already intense activity of the market as a whole in the region. Figure 2 compares the distribution of premiums issued by $\mathrm{D} \& \mathrm{O}$ insurance with that by all lines of insurance, by Brazilian region.

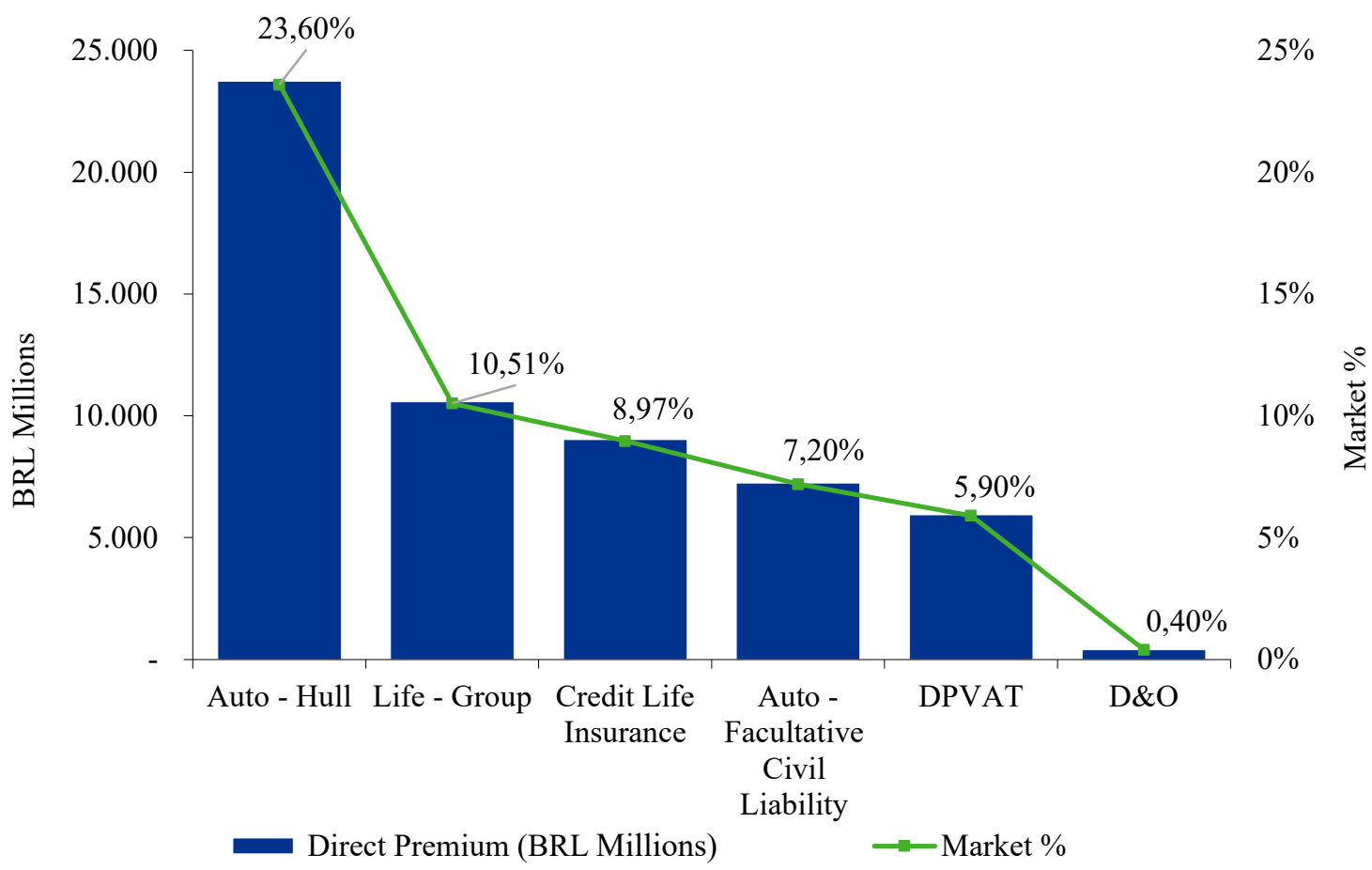

Figure 1. Direct premiums issued by line of insurance in 2017.

Source: authors, based on data from the SES-Susep database.

However, the timid result of the $\mathrm{D} \& \mathrm{O}$ insurance participation on the total of premiums underwritten in the Brazilian insurance market is not reflected when the real annual growth of premiums is observed. In that perspective, $\mathrm{D} \& \mathrm{O}$ insurance has a prominent place. Between 2004 and 2017, the accumulated real growth of direct premiums issued by the $\mathrm{D} \& \mathrm{O}$ line was higher than the entire insurance market. The years 2004, 2010, and 2015 were the most significant for the growth gap, in favor of the $\mathrm{D} \& \mathrm{O}$ insurance. Figure 3 shows the annual growth history between 2004 and 2017, comparing it with the Gross Domestic Product (GDP) growth.
In 2015, the annual growth of the $\mathrm{D} \& \mathrm{O}$ line was the highest in the historical series, both in absolute terms and in relation to the whole insurance market. Such development turns out to be even more unique due to its occurrence in a context of economic recession, signaled by the annual drop in GDP of $-3.77 \%$. The connection between $\mathrm{D} \& \mathrm{O}$ insurance and the Federal Police's investigation is not unprecedented. Fernandes and Guerra (2018) consider the operation to be a true watershed for the insurance market, causing insurers to be more cautious about underwriting the risk of their policyholders. 


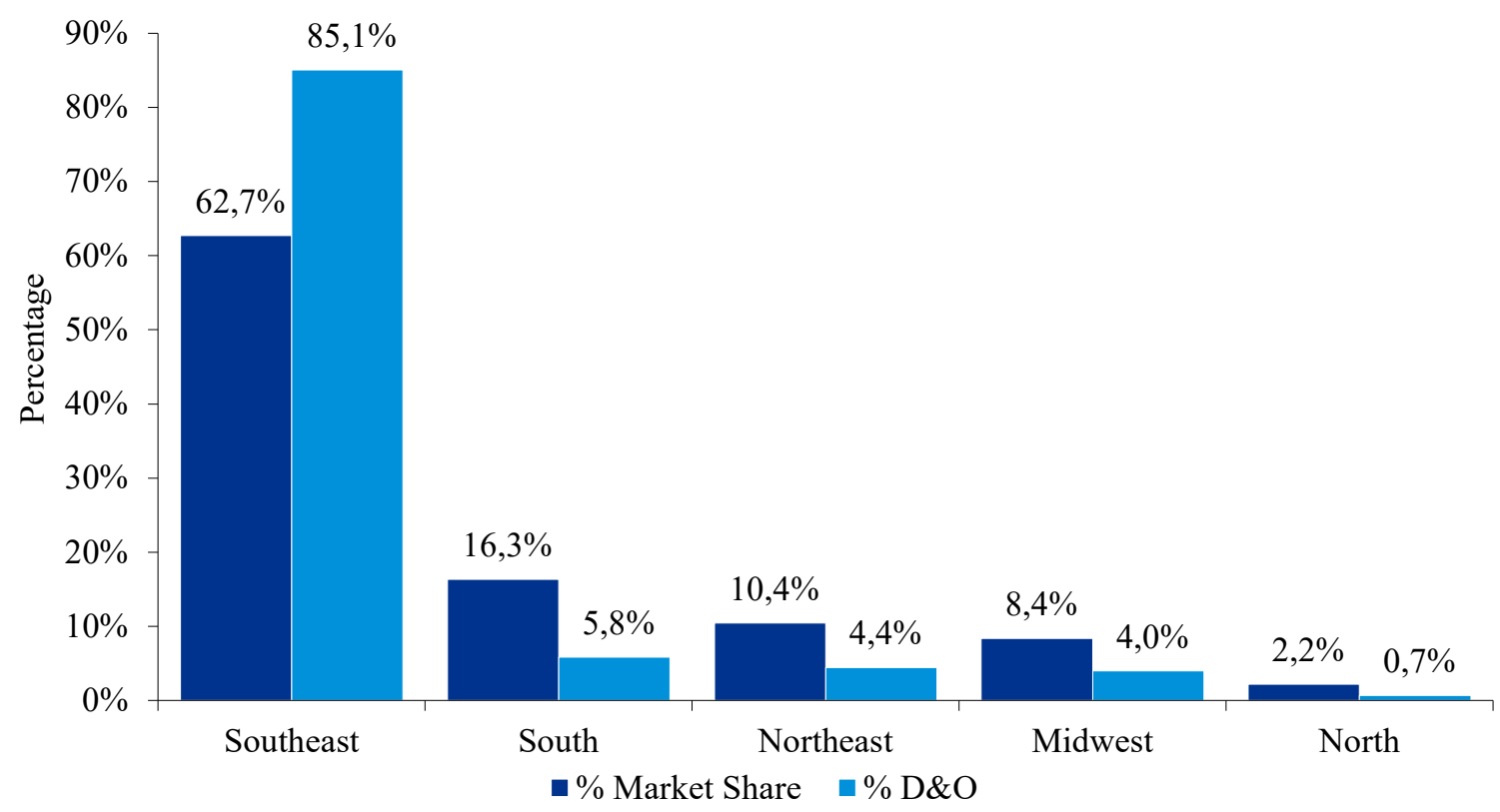

Figure 2. Distribution in 2017 of insurance market premiums and D\&O premiums in Brazil. Source: authors, based on data from the SES-Susep database.

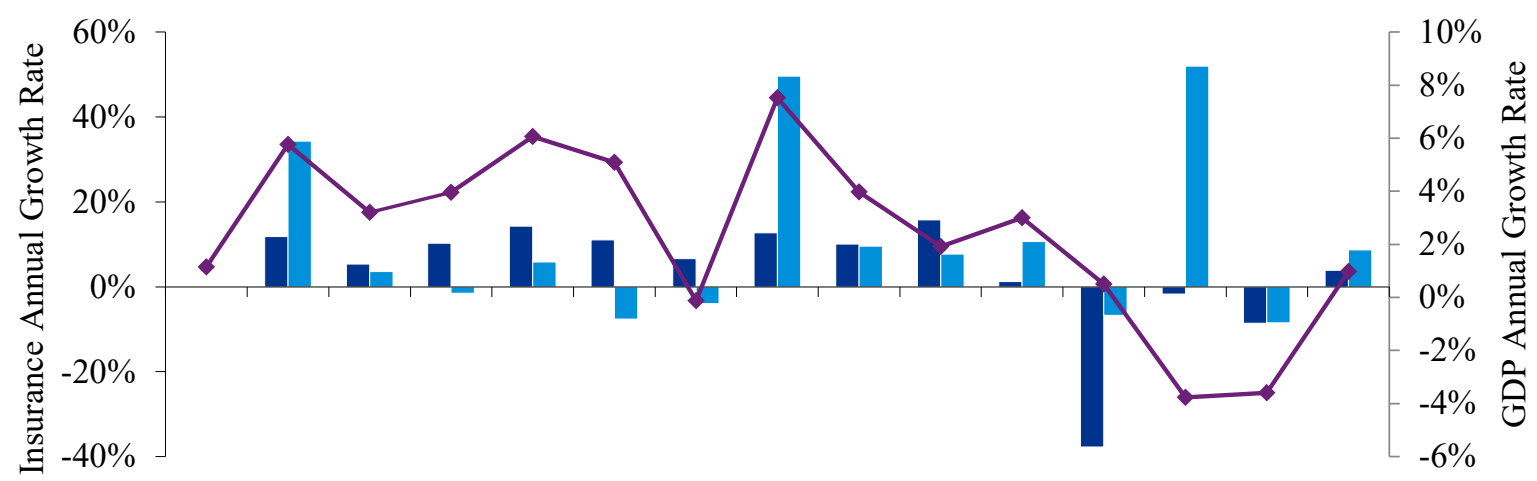

200320042005200620072008200920102011201220132014201520162017 $\triangle$ All Business Lines $\triangle \mathrm{D} \& \mathrm{O} \longrightarrow \Delta \mathrm{GDP}$

Figure 3. Real annual growth of insurance market premiums, D\&O premiums, and GDP (2003-2017).

Source: authors, based on data from the SES-Susep and Ipeadata databases.

Rodrigues (2011) links the D\&O insurance growth in 2004 to the beginning of the New Civil Code Law in January 2003 (Lei no. 10.406, 2002). The updating of the Civil Code Law has made corporate liability more rigid ${ }^{1}$, strengthening the concept of disregard of legal personality, which considers that the rights and duties of a juridical person can be extended to the rights and duties of the individuals who lead the entity at issue. The growth observed in the year 2010 is related to the movement of liability of executives after the 2008 subprime crisis. Faria (2015) considers that, in the Brazilian scenario, the event raised the perception of companies regarding financial risks they would be exposed to, as well as the executives' perception of the probability of being held responsible for their management acts.

What sets that research apart from previous publications is the quantitative methodology used to assess the $\mathrm{D} \& \mathrm{O}$ insurance market, an unparalleled approach in the Brazilian case. However, the qualitative explanations of 
Rodrigues (2011) and Faria (2015) about the moments of higher growth of the $\mathrm{D} \& \mathrm{O}$ line in Brazil corroborate the probability updating hypothesis (Fier et al., 2015), since the three years of highest growth observed (2004, 2010, and 2015) were preceded by events that raised the risk perception by economic agents. This research hypothesizes that the performance of $\mathrm{D} \& \mathrm{O}$ insurance in 2015 is related to the outbreak of CWO in 2014.

\section{THEORETICAL BACKGROUND AND EMPIRICAL LITERATURE}

\section{Demand for insurance and probability updating}

The previous literature on insurance demand and supply comes out, broadly, as an effort to identify and distinguish the factors that change the dynamics of that market law. The studies on this sector center around the standpoint of demand, with a shortage of works that assess the factors that influence the insurance supply (Fier $\&$ Liebenberg, 2014).

Jaspersen (2016) has compiled 95 research articles on demand for insurance from the main academic journals in the area since 1980, presenting the aspects of demand analyzed in each study and the methodology used to do so. Despite the plurality of objectives, resulting in specific contributions from each paper, the author concludes that all research address the theory of decision under uncertainty. That is an indication of a general characteristic to be considered in order to assess demand for insurance, regardless of the line in question.

The theory of decision under uncertainty serves as a basis for modeling the behavior of economic agents in situations where there is more than one possible result following the decision-making. This objective is intrinsically related to the insurance universe, since uncertainty, a fundamental measure to evaluate risks, is a necessary condition for agreeing on any contract in this segment because the outcome of the adverse event cannot be known in advance.

After the occurrence of an event with unwanted consequences, insurance contractors can base their perception of future losses on said event, raising their demand for protection, even if they have not been directly affected by the event. Thus, the increase in demand for protection may occur before the increase in insurance claims, with the possibility of the growth on the indemnities not even occurring, simply through a worsening of the perception of the risk materialization.
The literature calls this type of increase in demand as probability updating (Browne \& Hoyt, 2000; Fier et al., 2015; Froot \& O'Connell, 1997). The probability updating is heightened after catastrophic events, due to their severity and to the emphasis given to them by the media. Thus, the main pieces of evidence found in the literature on this effect are related to the demand for protection from natural disasters.

Froot and O'Connell (1997) assessed what the catastrophe risk pricing standards were for reinsurance companies in the United States after claims occurred. The results indicate that the increase in the price of reinsurance in that context is related to two factors: (a) the decrease in the capital available to reinsurers and (b) the shock of demand for insurance, caused by the change in the risk perception of economic agents. These results imply the incidence of probability updating.

Browne and Hoyt (2000) examined the experience of the National Flood Insurance Program (NFIP) in the United States between 1983 and 1993 to assess which determining variables for the acquisition of flood insurance there are. The NFIP is a US federal government's program that consists of subsidizing the acquisition costs of this line of insurance for families and companies. The results indicate three significant factors for the choice of acquiring insurance: the income, the insurance cost, and the recency of claims. Economic agents with higher incomes are more likely to buy a policy; the reduction in the cost of the insurance (which can happen by increasing the State subsidy) also produces an effect of increased demand. However, the main finding of the research is that the occurrence of floods causes an increase of insurance demand in subsequent periods, implying the effect of the probability updating.

Despite the greater recurrence of the probability updating in the catastrophic risk insurance line, its occurrence in other lines is possible, through an exogenous unforeseen event that comes to significantly affect the claims of the insurance line. Fier et al. (2015) assessed the effects of the probability updating on the demand for $\mathrm{D} \& \mathrm{O}$ insurances in a period of uncertainty on the liability of US executives (and, as a result, of the claims of D\&O insurance), in the context of the implementation of the Sarbanes-Oxley law (SOX).

SOX was sanctioned in 2002 as a reaction from the US government to the then-recent financial scandals of large companies. The scandals were related to accounting frauds involving manipulation of results to hide losses and inflate profits. Consequently, investors and other stakeholders incurred severe losses. The law imposed greater accountability mechanisms on the companies and the accountability of executives for compliance within their jurisdiction. 
To achieve their study goal, Fier et al. (2015) observed data on the demand for D\&O insurance, voluntarily provided by companies between 1991 and 2007, splitting that time interval into five periods related to higher or lower uncertainty about executive accountability. In addition, they divided companies into two groups: those impacted and those not impacted by corporate scandals. Impacted companies were those belonging to the sectors of finances, technology, transportation, communication, and services and utilities. Evidence was found that companies in sectors associated with corporate scandals in the early 2000s were more likely to demand $\mathrm{D} \& \mathrm{O}$ insurance in periods of uncertainty about executive accountability, suggesting that, when there is a perception of increased exposure to litigation, companies increase their coverage of that insurance. Finally, the authors conclude that firms with a higher risk of litigation are more prone to higher coverage.

\section{The insurance supply}

The analysis of CWO's influence on the D\&O insurance market growth in Brazil can be done both from the perspective of supply and of demand, since the value observed in one of the axes also refers to the other, due to the market equilibrium. In this research, it was decided to produce analysis from the perspective of supply, using the hired contracts, due to the following factors: (a) reliability and extension of the database made available by Susep; (b) easiness to describe the profile of the insurance companies that operate with $\mathrm{D} \& \mathrm{O}$; and (c) the absence of microdata available to model the decision of individuals and firms of purchasing that type of insurance. Therefore, we follow the study of Fier and Liebenberg (2014) closely.

The objective of Fier and Liebenberg (2014) consisted of identifying which characteristics of insurance companies influence their decision-making on underwriting $\mathrm{D} \& \mathrm{O}$ insurance coverage. To do so, they estimated a model with the D\&O insurance microdata of the United States between 2011 and 2012 available from the National Association of Insurance Commissioners (NAIC), the American insurance market regulator. The study was divided into two parts. The first is an analysis of the $\mathrm{D} \& \mathrm{O}$ insurance market in the United States, through descriptive statistics. Among the conclusions, one is that the $\mathrm{D} \& \mathrm{O}$ line is the eleventh-place property insurance line out of a total of 24 lines, under the criterion of earned premiums, representing a small percentage of the total premiums earned from all property lines $(0.74 \%)$. When analyzing the profile of the insurers that operate $\mathrm{D} \& \mathrm{O}$, it is possible to verify that the insurers which underwrite that type of risk are larger, less leveraged, and with a more diverse portfolio. However, there is also the presence of D\&O operators with different profiles.

The second part of the research consists of estimating a Cragg ${ }^{2}$ model (Cragg, 1971) for panel data, in two stages. The first stage uses a binary variable as response to represent the insurer's decision to subscribe or not to $\mathrm{D} \& \mathrm{O}$ insurance. The explanatory variables are composed of characteristics of the insurer (size, leverage, geographical diversification, portfolio diversification, the form of product distribution, and association with some insurance group). The second stage, in turn, has the same explanatory variables as the previous stage, but having the value of the premiums subscribed by the insurer at the time $\mathrm{t}$ as dependent. The procedure captures, according to the characteristics of the insurer, whether or not it subscribes to $\mathrm{D} \& \mathrm{O}$ insurance and, if so, in what magnitude.

The conclusions reached by the model are that insurance companies that operate with D\&O: (a) are significantly larger than those that do not operate with $\mathrm{D} \& \mathrm{O}$; (b) are more geographically diversified; (c) have more distribution channels for their products; (d) have lower leverage ratios and are more likely to continue in the $\mathrm{D} \& \mathrm{O}$ market. These factors affect both the insurers' decision to underwrite the $\mathrm{D} \& \mathrm{O}$ insurance risk and the volume of revenues.

\section{D\&Oinsurance and corporategovernance}

The Brazilian Corporate Governance Institute (IBCG) defines corporate governance as "the system by which companies and other organizations are run, monitored, and encouraged, involving the relationship between partners, board of directors, executive officers, supervisory and control agencies, and other stakeholders" (Instituto Brasileiro de Governança Corporativa [IBCG], 2018). A company's corporate governance structure serves as a primary driver of the way it operates and the environment it belongs to, supporting the analysis of its exposure to risks. High standards of corporate governance mitigate the risk of agent-to-principal and controlling-tominority shareholders type of agency conflicts.

$\mathrm{D} \& \mathrm{O}$ insurance has a high degree of corporate governance relation. However, there is no consensus in the literature about the effects of insurance on companies. Some research identify beneficial effects of D\&O insurance for the company (Holderness, 1990; Hwang \& Kim, 2018; Mayers \& Smith, 1982), research that identify harmful effects (Chalmers, Dann, \& Harford, 2002; Jia \& Tang, 2016; Lin et al., 2011; Zou, Wong, Shum, Xiong, \& Yan, 2008) and research that identify both (Boyer \& Tennyson, 2015; Liao \& Li, 2017). 
The harmful effects of D\&O insurance for the companies are generally related to the moral hazard of managerial opportunism of executives practicing acts on their interests, contrary to the will of the shareholders (Black, Cheffins, \& Klausner, 2005). Chalmers et al. (2002) used data from 72 IPOs in the United States between 1992 and 1996 and concluded that companies that had higher $\mathrm{D} \& \mathrm{O}$ insurance coverage performed worse in the capital market in the three years following the offer.

Zou, Wong, Shum, Xiong and Yan (2008) attested that the demand for $\mathrm{D} \& \mathrm{O}$ insurance in China has a positive relation with the degree of conflict of interest between controlling and minority shareholders, suggesting that the insurance has the attribution of protecting executives controlling litigation against minority shareholders. Lin, Officer and Zou (2011) examined the effects of D\&O on organizations mergers and acquisitions in Canada. In their results, they concluded that greater $\mathrm{D} \& \mathrm{O}$ coverage is related to lower profits in these operations and less synergy between companies. Jia and Tang (2016) examined the effects of $\mathrm{D} \& \mathrm{O}$ insurance coverage on the behavior of board members and its effectiveness in the governance in Chinese companies. The results suggest that $\mathrm{D} \& \mathrm{O}$ insurance coverage is related to the moral hazard of these executives, making them less efficient in their functions and also busier (they assume other executive functions in other companies).

The beneficial effects of $\mathrm{D} \& \mathrm{O}$ insurance are related to higher levels of corporate governance and operational efficiency. Holderness (1990) assessed the effect of D\&O insurance on the cost of monitoring US companies listed on the stock exchange. The author concludes that $\mathrm{D} \& \mathrm{O}$ insurance reduces the cost of monitoring shareholders, due to the actions of the insurers, which, before underwriting the risks, survey the history of the insured executives and determine minimum criteria for governance. Under this point of view, $\mathrm{D} \& \mathrm{O}$ insurance is beneficial to the company's shareholders, since they can count on the insurance company monitoring, which in turn has greater expertise and resources for such function. Donelson, Hopkins and Yust (2015), in turn, argue that, in cases of collective actions against securities fraud, D\&O insurance helps the parties to reach agreements, although it is a less determinant instrument for assigning the agreements' final values than for loss estimation.

Boyer and Tennyson (2015) tested hypotheses on the relation between the demand for $\mathrm{D} \& \mathrm{O}$ insurance and the size of the firm, the characteristics of its governance and its business risk, through the analysis of data from the Canadian companies panel. The variables used by the authors to represent the potential cost of shareholder lawsuits are significantly linked to the demand for $\mathrm{D} \& \mathrm{O}$ insurance. These variables include the risk of falling stock prices and the market value and capital structure of the company (proportion of shareholders over the number of shares). Another evidence found is the relation between $\mathrm{D} \& \mathrm{O}$ coverage and more aggressive profit management strategies, corroborating the increased moral hazard hypothesis. On the other hand, a positive aspect of $\mathrm{D} \& \mathrm{O}$ insurance for companies was found, due to the evidence of insurers monitoring corporate governance. That hypothesis involves the fact that insurers require certain corporate governance standards from companies, to underwrite risk, so that companies with $\mathrm{D} \& \mathrm{O}$ coverage met the requirements, corroborating the result obtained in Holderness (1990).

\section{Mayers and Smith (1982) conclude that D\&O} insurance reduces the adverse selection of executives. The idea is that the best executives do not accept to manage companies taking risks that may even escape their view. Thus, companies that do not provide $\mathrm{D} \& \mathrm{O}$ insurance coverage to their executives hire professionals who are willing to expose themselves to greater risks, generally less qualified than those who do not accept the position.

Hwang and Kim (2018) examined the effect of D\&O insurance on the firm value of South Korean companies between the years 2002 and 2008. The advantage of analyzing South Korean companies in that period is that there was an obligation to detail their $\mathrm{D} \& \mathrm{O}$ insurance policies on their balance sheets, providing researchers with a sample of $100 \%$ of the companies listed on the stock market. The authors found evidence that companies with $\mathrm{D} \& \mathrm{O}$ insurance coverage have greater value, that being even greater for companies with high growth margins. This result can be understood by the fact that $\mathrm{D} \& \mathrm{O}$ insurance coverage makes executives less risk averse to more daring management strategies, generating more growth opportunities for the company.

Liao and Li (2017) investigated the effects of D\&O insurance on the risk appetite of Taiwanese banks. As result, the authors concluded that institutions covered by $\mathrm{D} \& \mathrm{O}$ insurance have a greater risk appetite. However, that risk is mitigated if the insurance company that underwrites the insurance has a high-risk rating from a rating agency and/or is specialized in the $\mathrm{D} \& \mathrm{O}$ line. This result provides evidence that best insurers are more accurate in underwriting their risks and can serve as a signaling factor for the insured's minimum corporate governance standards. 


\section{Economic impact evidenced and caused by Operation Car Wash}

Due to its nature and developments, CWO is a topic of interest for studies of several areas of knowledge. Although there are inferences about the economic effects of the operation, quantitative studies that measure these impacts are more recent and still rare in the list of publications on the subject. Signor, Love, Vallim, Raupp and Olatunji (2019), for instance, measure the economic effect of crimes revealed by the operation but not assigned to it. Using a sample of 99 bidding processes of Petrobras, the Brazilian oil company, the authors bring evidence of the existence of a cartel that used to overestimate the value of auctions. They also bring evidence that the losses caused by that practice were greater than those admitted by the companies investigated in their leniency agreements.

Through event studies, Araújo, Rodrigues, MonteMor and Correia (2018) assessed the effects of the disclosure of CWO's corruption events on public companies listed on Brazilian stock market. The results indicate that CWO has a reducing effect on the market value of the companies mentioned in the investigations and a positive influence on the market value of the companies not mentioned which are competing with the investigated ones.

Using a similar methodology, Padula and Albuquerque (2018) analyzed the effect of government corruption events on shares of three Brazilian companies of great significance in the composition of the Ibovespa (Brazilian Stock Exchange index) and their respective ADRs. As a proxy for the events of corruption, they considered the disclosure of the phases of CWO in different periods, to understand the effect of diffusion and absorption of the news. The results showed the devaluation of the original assets and their ADRs, and consequently the reduction of national and international investment.

The quantitative evidence points to negative economic impacts from CWO on different indicators of the entities directly involved. In this article, the key hypothesis is that both the decision to offer and the revenues from underwriting $\mathrm{D} \& \mathrm{O}$ line by insurance companies are related to the outbreak of CWO in 2014. Thus, it will be possible to verify its impact on the Brazilian insurance market, contributing to the understanding of the behavior of economic agents in the context of disclosure of corruption and investigation of companies and executives.

\section{METHOD}

\section{Data and variables}

Data from the Brazilian insurance market, with emphasis on the $\mathrm{D} \& \mathrm{O}$ line, was analyzed in descriptive and quantitative form. The analysis of descriptive statistics compared the average of the characteristics of the insurance companies that provide $\mathrm{D} \& \mathrm{O}$ coverage with those which do not operate in that line of business. To estimate the effect of the CWO on the issuance of $\mathrm{D} \& \mathrm{O}$ insurance policies and the extent of the offered coverage, the two-stage model of Cragg (Cragg, 1971) was used.

Its first stage consists of a probit regression and aims to evaluate the status of the explained variable of $\mathrm{D} \& \mathrm{O}$ insurance underwriting. The second stage is composed of a truncated regression (dependent on the result of the first regression), whose objective is to measure the extent of the same explained variable from the first stage. That is, given that the $\mathrm{D} \& \mathrm{O}$ insurance underwriting has occurred, what the revenue volume of that underwriting would be. The methodology used by Fier and Liebenberg (2014) will be adapted to the data from the Brazilian market, with the addition of the variable related to the CWO.

Finally, to assess whether the effect of the CWO is exclusive to the $\mathrm{D} \& \mathrm{O}$ line of business or is valid for the whole insurance market, a control model of the extension of the coverage offered by insurance companies in all lines was used.

\section{Two-stage model - issue and volume of D\&O insurance coverage}

The first stage of the model estimates the conjunctural effect of the legal context represented by CWO and the insurers' characteristics in issuing or not $\mathrm{D} \& \mathrm{O}$ policies, described by Equation (1).

SubsD\&O $_{i, t}=\alpha+\beta_{1}$ Size $_{i, t}+\beta_{2}$ Leverage $_{i, t}+\beta_{3}$ GeoDiver $_{i, t}++\beta_{4}$ PortDiver $_{i, t}+\beta_{5}$ Group $_{i, t}+\beta_{6}$ Carwash $_{t}$

in which:

Subs $D \& O_{i, t}:$ a binary variable that identifies whether

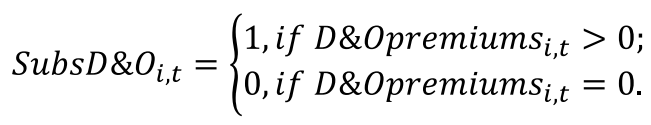

insurer $i$ has issued any D\&O insurance policy at the time $t$, defined by Equation (2).

Size $_{i, t}$ : indicates the total of assets under management of an insurer $i$ at the time $t$, on a natural logarithmic basis. 
Leverage $_{i, t}:$ is the investment conversion rate given by the proportion of the retained premium issued by insurance company $i$ in the time $t$ in relation to its net equity in the same period. The higher the rate, the greater the insurer's operational efficiency, as it retains more premiums in proportion to its equity. The calculation of that rate is indicated by Equation (3).

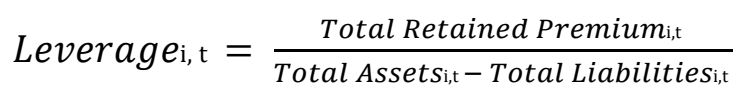

GeoDiver: it is a parameter of geographic concentration of activity of insurer $i$ at the time $t$, which varies between 0 and 1 . The closer to 1 , the more diversified the insurer is. That parameter is obtained by Equation (4).

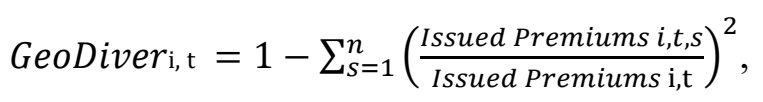

where $i$ represents the insurer, $t$ the time, and $s$ the state in which the premium was underwritten.

PortDiver $_{i, t}:$ a portfolio diversification parameter for insurer $i$ at the time $t$, which varies between 0 and 1 . The closer to 1 , the more diversified the insurer's portfolio is. That parameter is obtained by Equation (5).

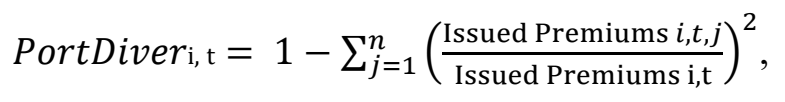

where $i$ represents the insurer, $t$ the time, and $j$ the insurance line of business.

Group $_{i, t}$ a binary variable that identifies whether insurer $i$ belongs to any economic group at the time $t$. Obtained by Equation (6).

Group $_{i, t}=\left\{\begin{array}{l}1, \text { if insurer } i \text { belongs to any group in month } t \\ 0, \text { if insurer } i \text { does not belong to any group in month } t .\end{array}\right.$

Carwash: a binary variable that identifies if there was any phase of Operation Car Wash at the time $t$. Obtained by Equation (7).

Carwash $_{t}=\left\{\begin{array}{l}1, \text { if there was any phase of CWO in month } t ; \\ 0, \text { if there was no CWO phase in month } t .\end{array}\right.$

Regarding the variable Leverage $_{i, t}$, which in the predecessor studies was calculated on a cash basis to calculate retained premiums, following NAIC's local recommendation, it is worth clarifying that the same cash basis methodology was used: 'direct premiums' (a current measure of direct revenues) and 'expense on reinsurance' (also current measure), to make the present study comparable with the previous ones.

The model's second stage estimates the conjunctural effect of the legal context represented by CWO and the insurers' characteristics in the total direct premiums of coverage offered by $\mathrm{D} \& \mathrm{O}$ insurance, described by Equation (8).

D\&Opremiums $_{i, t}=\alpha+\beta_{1}$ Size $_{i, t}+\beta_{2}$ Leverage $_{i, t}+\beta_{3}$ GeoDiver $_{i, t}++\beta_{4}$ PortDiver $_{i, t}+\beta_{5}$ Group $_{i, t}+\beta_{6}$ Carwash $_{t}$

in which the explanatory variables are the same as in the previous model and the dependent variable D\&Opremiums $s_{i, t}$ indicates the total of direct premiums issued by insurance company $i$ for $\mathrm{D} \& \mathrm{O}$ coverage at the time $t$, on a natural logarithmic basis.

The restriction of data to $\mathrm{D} \& \mathrm{O}$ insurance underwriting allows measuring how the factors present in Equation (1) relate to the total volume of direct premiums of $\mathrm{D} \& \mathrm{O}$ insurance policies issued. That is, the way insurers have increased or decreased their operations and revenues in that industry over time.

\section{Control model - coverage volume of all insurance lines}

The explanatory variables for this model are the same as for the two-stage model of $\mathrm{D} \& \mathrm{O}$ insurance. The difference is in the dependent variable: the amount of premiums issued by all lines by the insurer $i$ in the moment of time $t$. Thus, the model estimates the conjunctural effect of the legal context represented by CWO and the characteristics of insurers in the total of direct premiums for all lines of business offered, described by Equation (9).

The explanatory variables are the same as in the previous models and the dependent variable AllPremiums ${ }_{i, t}$ represents the total of direct premiums issued by insurance company $i$ in all lines of business, at the time $t$ in a natural logarithmic basis.

$$
\text { AllPremiums }_{i, t}=\alpha+\beta_{1} \text { Size }_{i, t}+\beta_{2} \text { Leverage }_{i, t}+\beta_{3} \text { GeoDiver }_{i, t}++\beta_{4} \text { PortDiver }_{i, t}+\beta_{5} \text { Group }_{i, t}+\beta_{6} \text { Carwash }_{t}
$$




\section{Empirical strategy and model specification}

The data for this study was displayed in panel. The unit of analysis is each one of the insurance companies operating in the market, assessing their idiosyncratic evolution over time. Data is monthly based and refers to the period between Jan./2003 and Dec./2017. The dynamics of the market, in which there is the discontinuation of operations and entry of new participants, causes the panel to be unbalanced. The database on premiums issued by insurance companies by line and the federative unit, as well as information on the capital structure of these entities, was obtained from SES (Brazilian insurance regulator statistics system).

To correct the effect of inflation on the monetary values of the data over time, it was used the monthly historical series of the IPCA, Índice Nacional de Preços ao Consumidor Amplo (Extended National Consumer Price Index), obtained from the database of Ipeadata, Instituto de Pesquisa Econômica Aplicada (Institute of Applied Economic Research), both official of the Brazilian government. Monetary data was brought to the present value to the last observed period (Dec./2017). Data on the CWO phases were obtained in the area of publications to the press from the Brazilian Federal Police website. Between Mar./2014 and Dec./2017, 47 phases were observed in 32 months.

\section{RESULTS}

\section{Descriptive analysis}

This section is intended for univariate comparison between insurers that subscribed $\mathrm{D} \& \mathrm{O}$ and those that did not subscribe it month by month, between January 2003 and December 2017. The comparison is made by distinguishing the values of the averages of the independent variables Size, Leverage, GeoDiver, PortDiver, and Group. In addition, it was verified the statistical significance between the difference of the averages of the two groups of insurers, through the application of the Student's t-test. Table 1 presents the results of that analysis.

Table 1. Comparison of insurance companies that subscribed D\&O or not between 2003 and 2017.

\begin{tabular}{|c|c|c|c|c|c|}
\hline Variable & Size & Leverage & GeoDiver & PortDiver & Group \\
\hline Average - all insurance companies $(\mathrm{n}=28,978)$ & 20.0277 & 0.1343 & 0.5683 & 0.4687 & 0.6536 \\
\hline Standard deviation — all insurance companies & 2.3812 & 3.2151 & 0.3006 & 0.3004 & 0.4868 \\
\hline $\begin{array}{l}\text { (1) Average - insurance companies that } \\
\text { underwrote } D \& O(n=1,686)\end{array}$ & 21.1273 & 0.1447 & 0.5886 & 0.7782 & 0.6892 \\
\hline $\begin{array}{l}\text { (2) Average - insurance companies that did not } \\
\text { underwrote } \mathrm{D} \& \mathrm{O}(\mathrm{n}=27,292)\end{array}$ & 19.9597 & 0.1336 & 0.5671 & 0.4496 & 0.6514 \\
\hline Average differences (1)-(2) & $1.1676^{* * *}$ & 0.0111 & $0.0215^{* * *}$ & $0.3286^{* * *}$ & $0.0378^{* * *}$ \\
\hline
\end{tabular}

Note. ${ }^{*}$ significant at $10 \%$; ${ }^{* *}$ significant at $5 \%$; ${ }^{* *}$ significant at $1 \%$. Source: authors.

Over the period analyzed, 28,978 observations were obtained, and in 1,686 of those there was D\&O insurance underwriting. The average difference between the insurers that underwrote $\mathrm{D} \& \mathrm{O}$ and those that did not is statistically significant at $1 \%$ for almost all the characteristics considered. On average, the insurance companies that underwrite $\mathrm{D} \& \mathrm{O}$ are larger, more likely to belong to an economic group, and have greater geographical and portfolio diversification. These results are similar to those obtained by Fier and Liebenberg (2014), corroborating the hypothesis that insurance companies that are larger on market share, with a more diversified portfolio and with a broader geographical reach, are more likely to supply specific products and/or with greater complexity.
The only variable that revealed no significant difference between the two groups observed was Leverage. That was also the only result that was different in those found by Fier and Liebenberg (2014). By its definition, the Leverage ratio represents the investment conversion rate, given by the proportion of the retained premium over the equity. The previous research pointed out that, on average, insurers that subscribe $\mathrm{D} \& \mathrm{O}$ have a lower Leverage ratio than those which do not operate in that line, indicating that insurers operating $\mathrm{D} \& \mathrm{O}$ in the United States obtain, on average, lower premium revenues than insurers that do not, given the same level of equity. In turn, the results obtained with Brazilian data indicate that the $\mathrm{D} \& \mathrm{O}$ line operation is indifferent to the market average for premium revenue. 
Table 2 compares the results obtained by Fier and Liebenberg (2014) based on NAIC data of 2011 and 2012 on the American insurance market with the values referent to the whole Brazilian market in two time frames: the whole observed period (from 2003 to 2017) and during the same period of NAIC data.

The non-significance of the difference in the average Leverage ratio of the insurers that operate or not the $\mathrm{D} \& \mathrm{O}$ insurance, as found in the Brazilian scenario, indicates that the attractiveness of the $\mathrm{D} \& \mathrm{O}$ line in Brazil, regarding returns on investment, is, on average, equal to the experience of the whole insurance market.

However, the comparison of Brazilian and American data provides another sign of greater significance: the Leverage ratio of the Brazilian market is substantially lower compared to that of the US market. On average, a monetary unit invested in an insurance company operating in Brazil results in 0.13 monetary unit of premiums written. This same investment in an insurance company operating in the United States results, on average, in 1.18 monetary units of premiums written, indicating a rate of premium revenue on invested capital about ten times higher.

Finally, it should be noted that there are insurers whose status in the group dummy has changed over time. There are two possible cases on the base: (a) independent insurance companies that were acquired by economic groups and became part of a conglomerate; and (b) insurance companies that were part of a conglomerate, but whose partnership was disbanded. Altogether, there are 62 cases between (a) and (b) of changes in the status of insurers as part of economic groups among 259 active entities at some point in time between 2003 and 2017.

Table 2. Average characteristics of insurance companies — Brazil and the United States.

\begin{tabular}{|c|c|c|c|}
\hline \multirow[b]{2}{*}{ Variable } & \multicolumn{3}{|c|}{ Sample } \\
\hline & $\begin{array}{c}\text { United States } \\
2011-2012 \\
\end{array}$ & $\begin{array}{c}\text { Brazil } \\
2011-2012 \\
\end{array}$ & $\begin{array}{c}\text { Brazil } \\
2003-2017\end{array}$ \\
\hline \multirow{2}{*}{ Size } & 18.0275 & 19.7086 & 20.0277 \\
\hline & (1.9935) & $(2.4815)$ & $(2.3812)$ \\
\hline \multirow{2}{*}{ Leverage } & 1.1806 & 0.0966 & 0.1343 \\
\hline & $(17.1580)$ & $(5.6658)$ & $(3.2151)$ \\
\hline \multirow{2}{*}{ GeoDiver } & 0.4281 & 0.5729 & 0.5683 \\
\hline & $(0.3901)$ & $(0.3047)$ & $(0.3006)$ \\
\hline \multirow{2}{*}{ PortDiver } & 0.3083 & 0.4671 & 0.4687 \\
\hline & $(0.2969)$ & $(0.2933)$ & $(0.3004)$ \\
\hline \multirow{2}{*}{ Group } & 0.6805 & 0.7005 & 0.6536 \\
\hline & $(0.4663)$ & $(0.4581)$ & $(0.4868)$ \\
\hline
\end{tabular}

Note. Standard deviation is in parentheses. Source: authors, with data from Susep and Fier, S. G., \& Liebenberg, A. P. (2014). The market for directors' and officers' insurance. Risk Management and Insurance Review, 17(2), 215-239. https://doi.org/10.1111/rmir.12023

\section{Results of models' estimation}

The models' objective is to assess whether CWO has significance in supplying $\mathrm{D} \& \mathrm{O}$ insurance. As a control, the effect of CWO on the extent of coverage underwritten in all insurance lines will be measured, to identify whether the magnitude of the effect of the CWO that occurred in the $\mathrm{D} \& \mathrm{O}$ line is specific to that line or recurring in the entire insurance market. Finally, the probability updating effect on the $\mathrm{D} \& \mathrm{O}$ insurance market caused by CWO will be estimated, via the denomination and inclusion of periods following the beginning of the operation.

To assess the probability of offering $\mathrm{D} \& \mathrm{O}$ insurance, a probit model was estimated for panel data, indicating whether there is or not a $\mathrm{D} \& \mathrm{O}$ insurance underwriting (first stage of the model of issuance and volume of $\mathrm{D} \& \mathrm{O}$ insurance coverage). To infer the extent of the coverage, general linear models were estimated for non-balanced panel data, with fixed and random effects (second stage of the model for both issuance and volume of $\mathrm{D} \& \mathrm{O}$ insurance coverage and control model). 
The data structure allowed insurance companies to be monitored over time. There is significance in the variance coefficient of the panel structure obtained in the probit model on the probability of supplying $\mathrm{D} \& \mathrm{O}$ insurance, a result favorable to the structuring of the data in this format. The non-balancing of the panel occurs because not all insurers operated at all times, incurring new entrants and exits caused by bankruptcies, mergers, or incorporations.
The coverage extension models - Equations (8) and (9) - were generated twice: with both fixed and random effects. The best adherence of the results to the sample was evaluated using the Hausman test. It was decided to present only the best adhered model results. All modeling results were obtained and can be provided by the authors upon request. Table 3 presents the results.

Table 3. Results of panel probit model for the underwriting decision Equation (1) and panel linear models for premium revenues Equations (8) and (9).

\begin{tabular}{|c|c|c|c|c|c|c|}
\hline \multirow{2}{*}{ Variável } & \multicolumn{2}{|c|}{ (1) Decision to supply D\&O } & \multicolumn{2}{|c|}{ (8) $\mathrm{D} \& \mathrm{O}$ extension } & \multicolumn{2}{|c|}{$\begin{array}{l}\text { (9) Extension - all lines — all } \\
\text { insurance companies }\end{array}$} \\
\hline & Coefficient & Standard error & Coefficient & Standard error & Coefficient & Standard error \\
\hline Intercept & $-1.6884^{* * *}$ & 0.6144 & -2.321838 & 1.5437 & - & - \\
\hline Size & $0.5845^{* * *}$ & 0.0309 & $0.6635^{* * *}$ & 0.0702 & $0.6288^{* * *}$ & 0.0112 \\
\hline Leverage & 0.0192 & 0.0330 & 0.5625 & 0.5543 & $0.003^{*}$ & 0.0020 \\
\hline GeoDiver & $-0.6363^{* * *}$ & 0.1657 & -0.1764 & 0.2190 & $0.5884^{* * *}$ & 0.0365 \\
\hline PortDiver & $3.5603^{* * *}$ & 0.2916 & $1.5617^{* * *}$ & 0.4166 & $1.3192^{* * *}$ & 0.0483 \\
\hline Group & $1.0543^{* * *}$ & 0.0826 & 0.1836 & 0.5328 & 0.0301 & 0.0341 \\
\hline Carwash & $0.4387^{* * *}$ & 0.0686 & 0.0815 & 0.0831 & $-0.3492^{* * *}$ & 0.0195 \\
\hline \multicolumn{3}{|c|}{ Hausman chi-square test } & \multicolumn{2}{|c|}{6.8886} & \multicolumn{2}{|c|}{62.762} \\
\hline \multicolumn{3}{|c|}{ Hausman p-value test } & \multicolumn{2}{|c|}{0.3313} & \multicolumn{2}{|c|}{0.0001} \\
\hline \multicolumn{3}{|c|}{ Estimation type } & \multicolumn{2}{|c|}{ Random effects } & \multicolumn{2}{|c|}{ Fixed effects } \\
\hline
\end{tabular}

Note. Legend: Size = natural logarithm of total assets; Leverage = = retained premium on equity; GeoDiver = geographic diversification; PortDiver = portfolio diversification; Group = indicator of belonging to economic group; Carwash = indicator of the CWO occurrence; ${ }^{*}$ significant at $10 \%$; ${ }^{* *}$ significant at $5 \%$; ${ }^{* * *}$ significant at $1 \%$. Source: authors.

\section{First stage - D\&O insurance underwriting probability model}

The results obtained from the estimation of the probit model in panel, for the underwriting decision, defined by Equation (1), are close to the findings in the descriptive analysis. According to Table 3, larger insurance companies that operate in different lines are more likely to supply $\mathrm{D} \& \mathrm{O}$ insurance, similar to the results obtained by Fier and Liebenberg (2014).

On the other hand, contrasting the authors, insurance companies operating in Brazil that belong to an economic group are more likely to supply $\mathrm{D} \& \mathrm{O}$ insurance, and the rate of conversion of equity into insurance premiums (Leverage) does not affect the probability of underwriting this insurance. The variable GeoDiver also diverges from the results of Fier and Liebenberg (2014): insurers with greater geographical diversification are less likely to operate the $\mathrm{D} \& \mathrm{O}$ line. However, the model's result is consistent with the data in Figure 3, that D\&O insurance policies are strongly concentrated in the southeast region of the country.

The Carwash indicates a statistically significant increase in the probability of insurers offering $\mathrm{D} \& \mathrm{O}$ insurance during the months in which CWO phases occurred, corroborating the hypothesis that the scale of that operation and its representativeness changed the executives' third party liability insurance market.

\section{Second stage - D\&O insurance underwriting volume model}

The results in Table 3 show a positive influence of $\mathrm{CWO}$ on the propensity of insurers to supply or not $\mathrm{D} \& \mathrm{O}$ insurance, controlled by the specific characteristics of the entities. In this subsection, the relation of these factors to the total premium revenue of this specific line of business 
is assessed. Table 3 presents the result of the model for the premiums revenues deriving from the decision to underwrite $\mathrm{D} \& \mathrm{O}$ insurance, defined by Equation (8).

According to Table 3, larger insurance companies (Size) that also operate in different lines (PortDiver) present higher revenue of premiums earned in the $\mathrm{D} \& \mathrm{O}$ line. Geographic diversification (GeoDiver) and belonging to an economic group (Group) affect the probability that insurers will supply D\&O insurance, but do not affect premium revenue from these operations.

Although the results of Equation (1) indicate the probability of an increase in the number of insurers that subscribe $\mathrm{D} \& \mathrm{O}$ in months when $\mathrm{CWO}$ phases occur, the results of Equation (8) show a non-significant effect on the direct premiums issued in the same period. In other words, an increase or decrease in the volume of direct premiums issued from $\mathrm{D} \& \mathrm{O}$ insurance is not expected in the months in which CWO phases occur.

This result suggests that if there is a relation between $\mathrm{CWO}$ and the D\&O insurance market, it does not occur immediately. The premise of a monthly-based effect would require influence not only of the operation but also of all its characteristics. This effect, then, being much more difficult, due to the quantity, heterogeneity, magnitude, amplitude, and temporality of the phases, so diverse they are.

\section{Control of effects - model for the revenues of the entire insurance market}

Finally, Table 3 shows the results for the last model, whose purpose is to compare the effects of CWO in the $\mathrm{D} \& \mathrm{O}$ insurance business and their effects on the entire insurance market. The results obtained in the two previous models indicate that the occurrence of CWO phases has a positive effect on the insurers' probability of offering that insurance, but not on the volume of direct premiums issued.

The comparative model was defined by Equation (9), which uses the same variables as the previous models, but now on the total direct premiums issued by the insurance companies, in all the insurance lines in operation. Thus, it is possible to assess whether the effect of CWO observed in the $\mathrm{D} \& \mathrm{O}$ line is specific to this line, or whether it is common to the entire Brazilian insurance market.

The results presented in Table 3 indicate that larger insurers (Size), more geographically diversified (GeoDiver) and with broader portfolios (PortDiver) have higher premium revenue. Geographic diversification, statistically significant for the volume of premiums earned in all lines, but not significant for the $\mathrm{D} \& \mathrm{O}$ line, is consistent with the high degree of concentration of this line's operation in the southeast region (shown in Figure 3).
The observed CWO effect is negative and statistically significant: caeteris paribus, a decrease of $0.3494 \%$ is expected in the total premiums revenue on insurance companies, regardless of the line, during the months in which there is some phase of the operation. Therefore, there is evidence that the occurrence of any phase of the operation is important enough to negatively affect the entire insurance market.

Thus, the results indicate a relation between the CWO phases and the drop in premium issuance across the market, in addition to insensitivity in the $\mathrm{D} \& \mathrm{O}$ line. But would this effect on the D\&O line be instantaneous? To test this possibility, the hypothesis of probability updating is used, which considers the influence of an exogenous oneoff event as a trigger for the increase in the demand for insurance. From this perspective, the outbreak of CWO is the trigger for updating of losses related to $\mathrm{D} \& \mathrm{O}$ insurance coverage, and its phases represent small waves of that initial effect.

In addition, the effect triggered by the operation is not immediately noticeable in the insurance market, not in the same month of its phases, but after a certain period. The division of CWO in periods after its outbreak, necessary for the perception of probability updating on the demand for $\mathrm{D} \& \mathrm{O}$ insurance, will be presented below.

\section{Estimated probability updating in $\mathrm{D} \& \mathrm{O}$ insurance}

The basic hypothesis of the effect of CWO on the probability updating the demand for $\mathrm{D} \& \mathrm{O}$ insurance is of recurrent sensitivity from the start of the operation, reverberating throughout its phases. That is because the process of changing the risk perception of economic agents can be triggered by a single event of high severity.

Therefore, it is more appropriate to measure the effect of CWO on the probability updating in $\mathrm{D} \& \mathrm{O}$ insurance, from the moment of its outbreak. For this purpose, models (1), (8), and (9) were re-estimated: the dummy Carwash, which indicated the occurrence of some phase of the operation at the time $t$, was excluded, and in its place, was put annual dummies of periods since the operation started. The definitions are given in Table 4.

The results of models (1), (8), and (9) estimation under these conditions are described in Table 5. 
Table 4. Periods of influence on executive accountability.

\begin{tabular}{ccc}
\hline Period & Calendar year & Characteristics of the period \\
\hline 1 & Mar./2014-Dec./2014 & CWO's first year \\
2 & 2015 & CWO's second year \\
3 & 2016 & CWO's third year \\
4 & 2017 & CWO's fourth year \\
\hline
\end{tabular}

Note. Source: authors.

Table 5. Results of the estimations of the panel models in Equations (1), (8), and (9) with a breakdown of post-CWO periods ${ }^{3}$.

\begin{tabular}{|c|c|c|c|c|c|c|}
\hline \multirow{2}{*}{ Variable } & \multicolumn{2}{|c|}{ (1) Decision for supplying D\&O } & \multicolumn{2}{|c|}{ (8) $\mathrm{D} \& \mathrm{O}$ extension } & \multicolumn{2}{|c|}{$\begin{array}{c}\text { (9) Extension - all lines — all insurance } \\
\text { companies }\end{array}$} \\
\hline & Coefficient & Standard error & Coefficient & Standard error & Coefficient & Standard error \\
\hline Intercept & $-16.8581^{* * *}$ & 0.6213 & - & - & - & - \\
\hline Size & $0.5673^{* * *}$ & 0.0296 & $0.4981^{* * *}$ & 0.0853 & $0.6728^{* * *}$ & 0.0116 \\
\hline Leverage & 0.0217 & 0.0284 & 0.6309 & 0.5561 & 0.0032 & 0.0020 \\
\hline GeoDiver & $0.5886^{* * *}$ & 0.1666 & -0.2158 & 0.2203 & $0.5466^{* * *}$ & 0.0364 \\
\hline PortDiver & $3.8643^{* * *}$ & 0.2390 & $1.4274^{* * *}$ & 0.4240 & $1.3187^{* * *}$ & 0.0480 \\
\hline Group & $1.0487^{* * *}$ & 0.0834 & -0.2716 & 0.9382 & 0.0548 & 0.0340 \\
\hline Period1 & $0.5783^{* * *}$ & 0.1163 & -0.0509 & 0.1292 & $-0.4575^{* * *}$ & 0.0308 \\
\hline Period2 & $0.4570^{* * *}$ & 0.1018 & $0.2177^{*}$ & 0.1237 & $-0.4338^{* * *}$ & 0.0291 \\
\hline Period3 & $0.5640^{* * *}$ & 0.1028 & $0.4016^{* *}$ & 0.1304 & $-0.4537^{* * *}$ & 0.0291 \\
\hline Period4 & $0.5755^{* * *}$ & 0.1030 & $0.6348^{* * *}$ & 0.1407 & $-0.3435^{* * *}$ & 0.0296 \\
\hline \multicolumn{3}{|c|}{ Hausman chi-square test } & \multicolumn{2}{|c|}{20.9750} & \multicolumn{2}{|c|}{49.143} \\
\hline \multicolumn{3}{|c|}{ Hausman p-value test } & \multicolumn{2}{|c|}{0.0127} & \multicolumn{2}{|c|}{0.0014} \\
\hline \multicolumn{3}{|c|}{ Estimation type } & \multicolumn{2}{|c|}{ Fixed effects } & \multicolumn{2}{|c|}{ Fixed effects } \\
\hline
\end{tabular}

Note. Legend: Size = natural logarithm of total assets; Leverage = retained on equity premium; GeoDiver = geographical diversification; PortDiver = portfolio diversification; Group = indicator of belonging to economic group; Period 1 = indicator of the first year of occurrence of CWO; Period $2=$ indicator of the second year of occurrence of the CWO; Period $3=$ indicator of the third year of occurrence of the CWO; Period $4=$ indicator of the fourth year of occurrence of the CWO; ${ }^{*}$ significant at $10 \%$; ${ }^{* *}$ significant at $5 \%$; ${ }^{* *}$ significant at $1 \%$. Source: authors.

The results presented in Table 5 of the model (1) indicate that, in all periods after the beginning of the operation, there was an increase in the probability of supplying D\&O insurance. Supporting the probability updating hypothesis, the results of the $\mathrm{D} \& \mathrm{O}$ premium extension model show an increase in the effect on D\&O premiums, with an increase also in their significance, since the beginning of the operation.

This indicates that the longer the operation lasts, the more information about its effects will be known and will be incorporated by economic agents, generating greater search for assets protection, either because more contracts were signed or because the cost per unit of insurance increased, implying greater premiums' revenue. In addition, the perpetuity of the effect of the operation three years after its beginning indicates not only the occurrence of the probability updating, but also the possible elevation of the
D\&O insurance market to a new level, and it can remain in it, caeteris paribus, even after the end of the operation.

The results of the model (9) indicate that the periods following the start of CWO are negatively significant, since the beginning of the operation. That means that either in the modeling that considers the months in which the phases of the operation occurred or in the modeling for periods after the beginning of the operation the CWO effect is, on average, more noticeable for the decrease of the entire insurance market than for the increase in the $\mathrm{D} \& \mathrm{O}$ line. This would justify the reasons for the performance detachment of this segment in relation to the rest of the insurance market.

Similarly to the negative effect verification of CWO in the capital market, brought by Araújo et al. (2018) and Padula and Albuquerque (2018), the results of the present 
study bring evidence of the adverse economic impacts of CWO in the insurance industry as a whole. However, there is evidence to state that insurers that have decided to operate contracts in the $\mathrm{D} \& \mathrm{O}$ business have benefited from having increased their monthly revenues.

There is a temporal endogeneity that accompanies the operation, of economic recession, which negatively affects the Brazilian GDP, in such a way that the insensitivity of the $\mathrm{D} \& \mathrm{O}$ line to this recession already indicates its uniqueness. In addition, part of this economic recession may have been caused by CWO itself, since among the companies investigated are the largest contractors in the country, which have left unfinished infrastructure works due to embargoes or lack of financing, whose operations are heavily dependent on contracting insurance.

Thus, there are subsidies to affirm that the practical effect of CWO in the entire insurance market is faster than the cognitive effect of the demand's probability updating for $\mathrm{D} \& \mathrm{O}$ insurance.

\section{FINAL REMARKS}

The $\mathrm{D} \& \mathrm{O}$ insurance transfers to the insurance companies the financial burden of executives, originated by the responsibility of acts performed in the exercise of functions in companies for which they were appointed, elected, and/or hired. Closely related to corporate governance, this type of insurance has been gaining importance in the US, European, and Asian insurance markets.

In Brazil, this line of business is still incipient, representing less than $0.50 \%$ of the entire market revenues. However, there has been an expressive growth of D\&O recently, in sync with changes in the Brazilian legal context. The change in the legal context refers to two moments of chronological order: the first concerns an environment of less accountability and penalization for executives, with greater predictability of the risk exposure of this function. The second stage is related to an environment of greater accountability and penalization for executives, resulting in uncertainty about the risk exposure of that public.

Based on the financial data of the insurance companies obtained from SES-Susep, an overview was made of the $\mathrm{D} \& \mathrm{O}$ insurance market in Brazil and its evolution. Furthermore, using panel data modeling, the degree of influence of CWO (representing a change in the legal context) was estimated, across the Brazilian insurance market and specifically in the D\&O line of business. The results point to CWO's significance for the $\mathrm{D} \& \mathrm{O}$ insurance market. As a control, the impact of CWO on the premiums' revenues in all insurance lines, by all insurance companies, was estimated. The result obtained indicates a negative relation between the operation and the direct premiums issued by the whole insurance market.

This set suggests that CWO generated effects on economic agents' probability updating over losses, resulting in higher direct premiums issued in the $\mathrm{D} \& \mathrm{O}$ line, either because more contracts were signed (risk updating by demand) or because the cost per insurance unit increased (risk updating by supply).

Attention should be paid to any bias due to endogeneity, which can occur for several reasons (variable omitted, simultaneity, selection bias, among others). Even though this research has adopted the same methodology used by Fier and Liebenberg (2014), in order to directly compare the results, it is recognized that that is a limited statistics processing to deal with that bias. For future research with similar scope, it is suggested the use of instrumental variables, as well as the use of models of differences in differences, in order to replicate the results and add robustness to the findings presented.

Due to the nature of the risks covered, protecting the insured one from financial penalties for wrongful guilty acts performed, there is a considerable probability of moral hazard in their demand, especially in a context such as the one observed, in which an executive investigation and accountability event is associated to an abrupt rise in the demand for insurance. On the other hand, risk taking is inherent to business activity, and the guarantee to administrators offered by $\mathrm{D} \& \mathrm{O}$ insurance is a tool that enables better management efficiency.

The recent $\mathrm{D} \& \mathrm{O}$ insurance evolution in Brazil creates challenges for all related parties: regulators, insurance companies, policyholders, and the judicial system. Changes in this type of insurance are expected to enable it to be associated with higher standards of corporate governance and operational efficiency. This research provides unprecedented quantitative subsidies for the Brazilian case, regarding $\mathrm{D} \& \mathrm{O}$ insurance in Brazil, for discussions related to coverage limits, types of risks involved, the formation of technical provisions, and legality of contracts. 


\section{NOTES}

1. This characteristic of the New Civil Code Law is expressed in Section 50: "In case of abuse of legal personality, characterized by misuse of purpose or assets indiscrimination, the judge may decide, at the request of the party, or the Public Prosecutor's Office when it is necessary to intervene in the process, that the effects of certain and stated relations of obligations are extended to the private assets of the administrators or partners of the legal person”.

\section{REFERENCES}

Araújo, E. C. C., Rodrigues, V. R. S., Monte-Mor, D. S., \& Correia, R. D. (2018). Corrupção e valor de mercado: os efeitos da Operação Lava Jato sobre o mercado de açóes no Brasil. Revista Catarinense Da Ciência Contábil, 17(51), 41-58. https://doi.org/10.16930/2237-7662/rccc.v17n51.2626

Black, B., Cheffins, B., \& Klausner, M. (2005). Liability risk for outside directors: A Cross-Border analysis. European Financial Management, 11(2), 153-171. https://doi.org/10.1111/j.1354-7798.2005.00280.x

Born, P. H., \& Klimaszewski-Blettner, B. (2013). Should I stay or should I go? The impact of natural disasters and regulation on U.S. property insurers' supply decisions. Journal of Risk and Insurance, 80(1), 1-36. https://doi.org/10.1111/j.1539-6975.2012.01477.x

Boyer, M. M., \& Tennyson, S. (2015). Directors' and Officers' Liability Insurance, Corporate Risk and Risk Taking: New Panel Data Evidence on The Role of Directors' and Officers' Liability Insurance. Journal of Risk and Insurance, 82(4), 753-791. https://doi.org/10.1111/jori.12107

Browne,M.J., \&Hoyt, R.E.(2000). TheDemandforFloodInsurance: Empirical Evidence. Journal of Risk and Uncertainty, 20(3), 291-306. https://doi.org/10.1023/A:1007823631497

Chalmers, J. M. R., Dann, L. Y., \& Harford, J. (2002). Managerial opportunism? Evidence from directors' and officers' insurance purchases. Journal of Finance, 57(2), 609-636. https://doi.org/10.1111/1540-6261.00436

Cragg, J. G. (1971). Some statistical models for limited dependent variables with application to the demand for durable goods. Econometrica, 39(5), 829. https://doi.org/10.2307/1909582

Donelson, D. C., Hopkins, J. J., \& Yust, C. G. (2015). The Role of Directors' and Officers' Insurance in Securities Fraud Class Action Settlements. The Journal of Law and Economics, 58(4), 747-778. https://doi.org/10.1086/684296

Faria, C. B. L. (2015). O Seguro D\&O e a Proteção ao Patrimônio dos Administradores (2 ${ }^{\text {nd }}$ ed). São Paulo: Almediana.
2. The Cragg methodology was used as an alternative to the Tobit model because it allows the variables included to have different effects at each of the estimation stages.

3. To evaluate some potential selection bias problem, models (1) and (8) were re-estimated using the two-stage model with Heckman (1979) correction to evaluate the robustness of the results. As it was estimated $r=0.16531$, with a p-value equal to 0.118 , it is concluded that there is no bias due to eventually omitted variables.

Fernandes, J. C., \& Guerra, R. H. e S. (2018). O seguro D\&O como instrumento de proteçáo dos administradores de sociedade empresárias. Revista Eletrônica de Direito Do Centro Universitário Newton Paiva, 34(1), 106-128. Retrieved from http://revistas.newtonpaiva.br/redcunp/ wp-content/uploads/2020/05/DIR34_08.pdf

Fier, S. G., \& Liebenberg, A. P. (2014). The market for directors' and officers' insurance. Risk Management and Insurance Review, 17(2), 215-239. https://doi.org/10.1111/rmir.12023

Fier, S. G., McCullough, K. A., Gabel, J. T. A., \& Mansfield, N. R. (2015). Probability updating and the market for directors' and officers' insurance. Risk Management and Insurance Review, 18(1),55-75.https://doi.org/10.1111/rmir.12029

Froot, K., \& O'Connell, P. (1997). The Pricing of U.S Catastrophe Reinsurance. NBER Working Paper, 60443. https://doi.org/10.3386/w6043

Gillan, S. L., \& Panasian, C. A. (2015). On lawsuits, corporate governance, and directors' and officers' liability insurance. Journal of Risk and Insurance, 82(4), 793-822. https://doi.org/10.1111/jori.12043

Heckman, J. J. (1979). Sample selection bias as a specification error. Econometrica, 47(1), 153-161. https://doi.org/10.2307/1912352

Holderness, C. G. (1990). Liability insurers as corporate monitors. International Review of Law and Economics, 10(2), 115-129. https://doi.org/10.1016/0144-8188(90)90018-O

Hwang, J. H., \& Kim, B. (2018). Directors' and officers' liability insurance and firm value. Journal of Risk and Insurance, 85(2), 447-482. https://doi.org/10.1111/jori.12136

Instituto Brasileiro de Governança Corporativa (IBGC). (2018). $O$ que é governança corporativa. São Paulo: IBGC. Retrieved from https://www.ibgc.org.br/conhecimento/governancacorporativa

Jaspersen,J.G. (2016). Hypothetical surveysand experimental studies of insurance demand: A review. Journalof Risk and Insurance, 83(1), 217-255. https://doi.org/10.1111/jori.12100 
Jia, N., \& Tang, X. (2016). Directors' and officers' liability insurance, independent director behavior, and governance effect. Journal of Risk and Insurance, 85(4), 1013-1054. https://doi.org/10.1111/jori.12193

Lei $n^{\circ}$ 10.406, de 10 de Janeiro de 2002 (2002). Institui o Código Civil. Retrieved from http://www.planalto.gov.br/ ccivil 03/Leis/2002/L10406.htm

Liao, Y. P., \& Li, K. F. (2017). Does directors and officers' liability insurance induce bank risk-taking? Evidence from Taiwan. Asia-Pacific Journal of Financial Studies, 46(1), 64-86. https://doi.org/10.1111/ajfs.12163

Lin, C., Officer, M. S., \& Zou, H. (2011). Directors' and officers' liability insurance and acquisition outcomes. Journal of Financial Economics, 102(3), 507-525. https://doi.org/10.1016/j.jfineco.2011.08.004

Macedo, M. A. S., \& Corrar, L. J. (2010). Análise do desempenho contábil-financeiro de seguradoras no Brasil no ano de 2007: Um estudo apoiado em análise hierárquica (AHP). Contabilidade Vista \& Revista, 21(3), 135-165. Retrieved from https://revistas.face.ufmg.br/index.php/ contabilidadevistaerevista/article/view/676

Macedo, M. A. S., Silva, F. F., \& Santos, R. M. (2006). Análise do mercado de seguros no Brasil: uma visão do desempenho organizacional das seguradoras no ano de 2003. Revista Contabilidade \& Finanças, 17(spe2), 88-100. https://doi.org/10.1590/S1519-70772006000500007

\section{Authorship}

\section{Rafael Tonet Rensi}

Universidade de Sáo Paulo, Faculdade de Economia, Administração, Contabilidade e Atuária

Av. Luciano Gualberto, no 908, Butantã, 05508-010, São Paulo, SP, Brazil.

E-mail address: rafael.rensi@usp.br

(1) https://orcid.org/0000-0001-6311-9058

\section{João Vinícius França Carvalho*}

Universidade de São Paulo, Faculdade de Economia, Administração, Contabilidade e Atuária

Av. Luciano Gualberto, no 908, Butantá, 05508-010, São Paulo, SP, Brazil.

E-mail address: jvfcarvalho@usp.br

(1) https://orcid.org/0000-0002-1076-662X

* Corresponding Author

\section{Funding}

There are no funders to report for this article.

\section{Conflict of Interests}

The authors have stated that there is no conflict of interest.
Mayers, D., \& Smith, C. W. (1982). On the corporate demand for insurance. The JournalofBusiness, 55(2), 281-296. Retrieved from https://www.jstor.org/stable/2352704?seq=1

Padula, A. J. A., \& Albuquerque, P. H. M. (2018). Corrupçáo governamental no mercado de capitais: um estudo acerca da Operaçáo Lava Jato. Revista de Administração de Empresas, 58(4), 405-417. https://doi.org/10.1590/s0034-759020180406

Rodrigues, A. C. (2011). A responsabilidade civil dos administradores de companhias abertas não financeiras por danos causados à sociedade e aos acionistas e o desenvolvimento do mercado de valores mobiliários brasileiro (Dissertação de mestrado). Fundação Getúlio Vargas, São Paulo, Brasil.

Signor, R., Love, P. E. D., Vallim, J. J. C. B., Raupp, A. B., \& Olatunji, O. (2019). It is not collusion unless you get caught: the case of 'Operation Car Wash' and unearthing of a Cartel. Journal of Antitrust Enforcement, 7(2), 177202. https://doi.org/10.1093/jaenfo/jnz009

Zou, H., Wong, S., Shum, C., Xiong, J., \& Yan, J. (2008). Controlling-minority shareholder incentive conflicts and directors' and officers' liability insurance: Evidence from China. Journal of Banking and Finance, 32(12), 26362645. https://doi.org/10.1016/j.jbankfin.2008.05.015

\section{Authors' Contributions}

$1^{\text {st }}$ author: conceptualization (equal); data curation (equal); formal analysis (equal); investigation (equal); methodology (equal); software (equal); validation (equal); visualization (equal); writing-original draft (equal); writing-review \& editing (equal).

$2^{\text {nd }}$ author: conceptualization (equal); data curation (equal); formal analysis (equal); investigation (equal); methodology (equal); project administration (lead); software (equal); supervision (lead); validation (equal); visualization (equal); writing-original draft (equal); writing-review \& editing (equal).

\section{Copyrights}

RAC owns the copyright to this content.

\section{Plagiarism Check}

The RAC maintains the practice of submitting all documents approved for publication to the plagiarism check, using specific tools, e.g.: iThenticate. 


\section{Peer Review Method}

This content was evaluated using the double-blind peer review process. The disclosure of the reviewers' information on the first page, as well as the Peer Review Report, is made only after concluding the evaluation process, and with the voluntary consent of the respective reviewers and authors.

\section{Data Availability}

All data and materials were made publicly available through the Mendeley platform and can be accessed at:

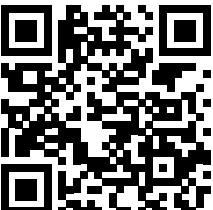

Carvalho, Joao Vinicius; Rensi, Rafael (2020), "Data for Car Wash Operation: impacts on the executives' liability insurance market", Mendeley

Data, v1. http://dx.doi.org/10.17632/z5xrgrycvv.1 